\title{
EFFECTS OF ANTHROPOGENE POLLUTION ON URBAN ECOSYSTEM
}

\author{
${ }^{1}$ Misliddin Muhammatovich Khalmatov, ${ }^{2}$ Bokhodirkhodja \\ Sharibkhodjaevich Ismoilkhodjaev, ${ }^{3}$ Dilmurod Dekhkanovich Khusanov, \\ ${ }^{4}$ Hamdam Tursunov
} ${ }^{1} \mathrm{RhD}$ researcher of Andizhan Machine Building Institute, Andizhan region, Republic of
Uzbekistan

${ }^{2}$ Professor of Tashkent Institute of Irrigation and Agricultural Mechanization Engineers, Tashkent, Republic of Uzbekistan

${ }^{3}$ Assistant of Andizhan Institute of Agriculture and Agrotechnology, Andizhan region, Republic of Uzbekistan

${ }^{4}$ Assistant of Andizhan Machine Building Institute, Andizhan region, Republic of Uzbekistan

Article DOI: https://doi.org/10.36713/epra6785

DOI No: 10.36713/epra6785

\begin{abstract}
According to the results of the correlative modeling regression, there is a strong correlation link between the concentration of harmful substances in the atmosphere and the amount of tree accumulation in the leaves. Such bonding was most prominent at juniper trees. In particular, the density of binding between the two sulphate proteins and the accumulation of this substance in the leaf of selected trees was 0.88 in the juniper tree, 0.78 in the oak tree, 0.75 in the chestnut, and 0.93 in the pavlonion tree.
\end{abstract}

KEY WORDS: Ecosystem, atmosphere, leaves, substances, trees, pests, urban, connection, linear connection, regression, correlation, chlorophyll.

\section{INTRODUCTION}

Atmospheric pollutants affect living organisms in the form of biochemical agents, leading to disruptions in the ultramicroscopic structure of the cell. This leads to physiological processes and metabolism of plants and leads to a decrease in its productivity and growth rate, life expectancy. In ecosystems, depending on the genetic characteristics of trees, the effects of pollutants on them of different types and levels may be different. The level of stress on trees by atmospheric substances develops in two situations, such as the amount of time in limited time intervals or the accumulation over a long period of time.

Due to the release of industrial or other types of anthropogenic substances into the atmosphere, their concentration changes and accumulation in soil and vegetation in certain areas is observed. Research in this areafirst time McLaughlin SB [1]. led in the 1980s. During this period, sulfur dioxide was the main air pollutant in Europe and America, as well as in the Soviet Union. The fact that the first joint scientific project of Soviet and American scientists in the 1980s also focused on the 


\section{SJIF Impact Factor 2021: 8.013| ISI I.F.Value:1.241| Journal DOI: 10.36713/epra2016 ISSN: 2455-7838(Online) EPRA International Journal of Research and Development (IJRD) Volume: 6 | Issue: 5 | May 2021 - Peer Reviewed Journal}

impact of forest ecosystems and pollutants shows how problematic the effects of substances on trees were during this period [2]. To date, research in this area is extensive and specific to each region.

By the end of the last century, acid rain had emerged, which was one of the main threats to the tree ecosystem. Actually acid rainAlthough the emergence of ing was observed in the Middle Ages, the scale of today's anthropogenic changes, the concentration of industrial and domestic wastes in the atmosphere began to become dangerous, led to an increase in the intensity of acid rain [3].

Based on the results of research, with the increase of atmospheric pollutants, the tree ecosystem in the world's forest region has lost $45 \%$ of its viability [4]. Today, in the study of tree changes in the world, a method of diagnosis and classification based on changes in the morphology of the tree, consisting of 12 points, has been applied [5]. The purpose of this study is to study the relationship between the accumulation of pollutants in trees in the context of the concentration of pollutants in the atmosphere in the city of Andijan.

\section{RESEARCH METHODOLOGY}

The method of studying the accumulation of these substances in the leaves of different trees with atmospheric concentrations of pollutants in the study area is to analyze them by modeling simple statistical relationships. To do this, a correlation between the two variables under study was identified and their reliability was assessed.

The detected concentration of harmful substances in the atmosphere was determined using the analysis of samples taken from tree leaves at the same time. Under such conditions, it is not possible to determine the intensity of accumulation. The reason is harmful to the atmosphereThe accumulation of substances in a tree leaf takes place at certain intervals.

The analysis of the interdependencies is based on a linear regression equation:

$$
y_{x}=a_{0}+a_{1} x
$$

Here, the a1-parameter is called the regression rate, and it represents the factor character efficiency or, conversely, the rate of decrease, i.e., how much the resulting variable increases when the character value increases by one unit. Based on this straight-line equation, the correlation coefficient of the correlation density of changes in the amount of matter in tree leaves with increasing concentration of harmful substances in the atmosphere was determined:

$$
r_{x y}=\frac{\sum(x-\bar{x})(y-\bar{y})}{\sqrt{\sum(x-\bar{x})^{2} \sum(y-\bar{y})^{2}}}
$$

The bond is weak if the bond density lies in the range of \pm 0.30 .5 ; The connection is average if it lies in the range of \pm 0.50 .8 ; If it lies in the range of \pm 0.81 .0 , the bond is considered strong [6].

During the correlation analysis, a 95\% confidence interval was selected to determine the reliability between the mean and the variance [7].

\section{THE RESULTS OBTAINED AND THEIR DISCUSSION}

The atmosphere is a practically unlimited air phase in which physical and chemical processes are essential for the survival of a living organism. The presence of anthropogenic pollutants in the air cavity and its concentration have a detrimental effect on the human body, primarily secondary [8]. This effect is manifested in latent, regular and irreversible forms in trees. The effect at low concentrations, in turn, does not cause rapid symptoms in plants, but disrupts physiological processes. While regular exposure adversely affects the chlorophyll process, irreversibly the concentration of substances in the atmosphere causes the tree to self-destruct due to the inability of the tree stem to absorb water by the mesophilization process or the unusual shedding process of the leaf.

Studies have shown that trees have a detrimental effect on tree ecosystems when their resistance to such substances does not exceed the level of their adaptive properties.a can not. Such a concentration limit was expressed in 1984 in the following figures: the maximum value of $\mathrm{NO} 2$ in the atmosphere is a maximum of $0.04 \mathrm{mg}$ per cubic meter of air, an average of $0.02 \mathrm{mg}$ per day; maximum level for lead $0.01 \mathrm{mg}$, average daily 0.002 $\mathrm{mg}$, maximum value for $\mathrm{SO} 23.0 \mathrm{mg}$ daily maximum $1.0 \mathrm{mg}$; for formaldehyde, the maximum was set at $0.02 \mathrm{mg}$, with an average of $0.003 \mathrm{mg}$ daily (Table $1)$.

The results of regression correlative modeling revealed a strong correlation between the concentration of harmful substances in the atmosphere and the amount of accumulation in the leaves of trees. Such a connection was especially evident in the spruce tree.

In particular, the density of the bond between the two oxides of sulfate and the accumulation of this substance in the leaves of selected trees was 0.88 in spruce, 0.78 in oak, 0.75 in chestnut and 0.93 in pavlovnia. (You can see the reliability of this correlation equation in Figure 1, point a). 


\section{EPRA International Journal of Research and Development (IJRD)}

Volume: 6 | Issue: 5 | May 2021

- Peer Reviewed Journal

\section{Table 1}

Parameters of the regression model equation between harmful substances in the atmosphere and their amounts in tree leaves

(In modeling, the dependence of SO2, $\mathrm{Pb}, \mathrm{NO2}$, formaldehyde in the atmosphere on the leaves of four trees was studied)

\begin{tabular}{|c|c|c|}
\hline Indicators & Linear equation & $\begin{array}{l}\text { Correlation } \\
\text { coefficient }\end{array}$ \\
\hline \multicolumn{3}{|c|}{ SO2 } \\
\hline Spruce tree & SO2 $=-0.07730+46.68814 *$ Spruce tree $(\mathrm{mg} / \mathrm{kg})$ & 0.82 \\
\hline Oak tree & SO2 $=0.21984+59.87591 *$ Oak tree $(\mathrm{mg} / \mathrm{kg})$ & 0.78 \\
\hline Chestnut tree & SO2 $=0.16420+29.36898 *$ Chestnut tree $(\mathrm{mg} / \mathrm{kg})$ & 0.75 \\
\hline Pavlonia tree & SO2 $=0.13524+40.40275 *$ Pavlonia tree $(\mathrm{mg} / \mathrm{kg})$ & 0.93 \\
\hline \multicolumn{3}{|c|}{$\mathbf{P b}$} \\
\hline Spruce tree & $\mathrm{Pb}=0.00040+0.10578 *$ Spruce tree $(\mathrm{mg} / \mathrm{kg})$ & 0.26 \\
\hline Oak tree & $\mathrm{Pb}=0.00149-0.07229 * 0 a k$ tree $(\mathrm{mg} / \mathrm{kg})$ & 0.009 \\
\hline Chestnut tree & $\mathrm{Pb}=0.00254-0.64074 *$ Chestnut tree $(\mathrm{mg} / \mathrm{kg})$ & -0.38 \\
\hline Pavlonia tree & $\mathrm{Pb}=0.00047+0.35000 *$ Pavlonia tree $(\mathrm{mg} / \mathrm{kg})$ & 0.02 \\
\hline \multicolumn{3}{|c|}{ NO2 } \\
\hline Spruce tree & $\mathrm{NO} 2=0.01750+2.33779 *$ Spruce tree $(\mathrm{mg} / \mathrm{kg})$ & 0.95 \\
\hline Oak tree & $\mathrm{NO} 2=0.02509+2.35516 *$ Oak tree $(\mathrm{mg} / \mathrm{kg})$ & 0.94 \\
\hline Chestnut tree & NO2 $=0.33119-2.25072 *$ Chestnut tree $(\mathrm{mg} / \mathrm{kg})$ & -0.08 \\
\hline Pavlonia tree & $\mathrm{NO} 2=0.05545+4.00437 *$ Pavlonia tree $(\mathrm{mg} / \mathrm{kg})$ & 0.80 \\
\hline \multicolumn{3}{|c|}{ Formaldehyde } \\
\hline Spruce tree & $\begin{array}{l}\text { Formaldehyde }=0.00631+42.25027 * \text { Spruce tree }(\mathrm{mg} \\
/ \mathrm{kg})\end{array}$ & 0.78 \\
\hline Oak tree & $\begin{array}{l}\text { Formaldehyde }=0.00948+32.48659 * \text { Oak tree }(\mathrm{mg} / \\
\mathrm{kg})\end{array}$ & 0.53 \\
\hline Chestnut tree & $\begin{array}{l}\text { Formaldehyde }=0.00904+14.17263 * \text { Chestnut tree } \\
(\mathrm{mg} / \mathrm{kg})\end{array}$ & 0.71 \\
\hline Pavlonia tree & $\begin{array}{l}\text { Formaldehyde }=0.01177+15.13008 * \text { Pavlonia tree } \\
(\mathrm{mg} / \mathrm{kg})\end{array}$ & 0.62 \\
\hline \multicolumn{3}{|c|}{ 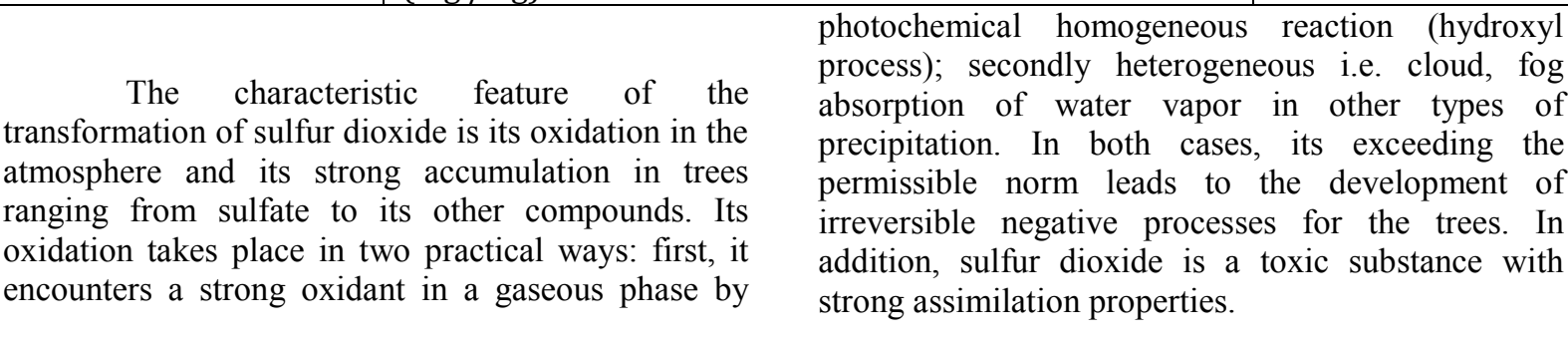 } \\
\hline
\end{tabular}




\section{EPRA International Journal of Research and Development (IJRD)}

Volume: 6 | Issue: 5 | May 2021 - Peer Reviewed Journal
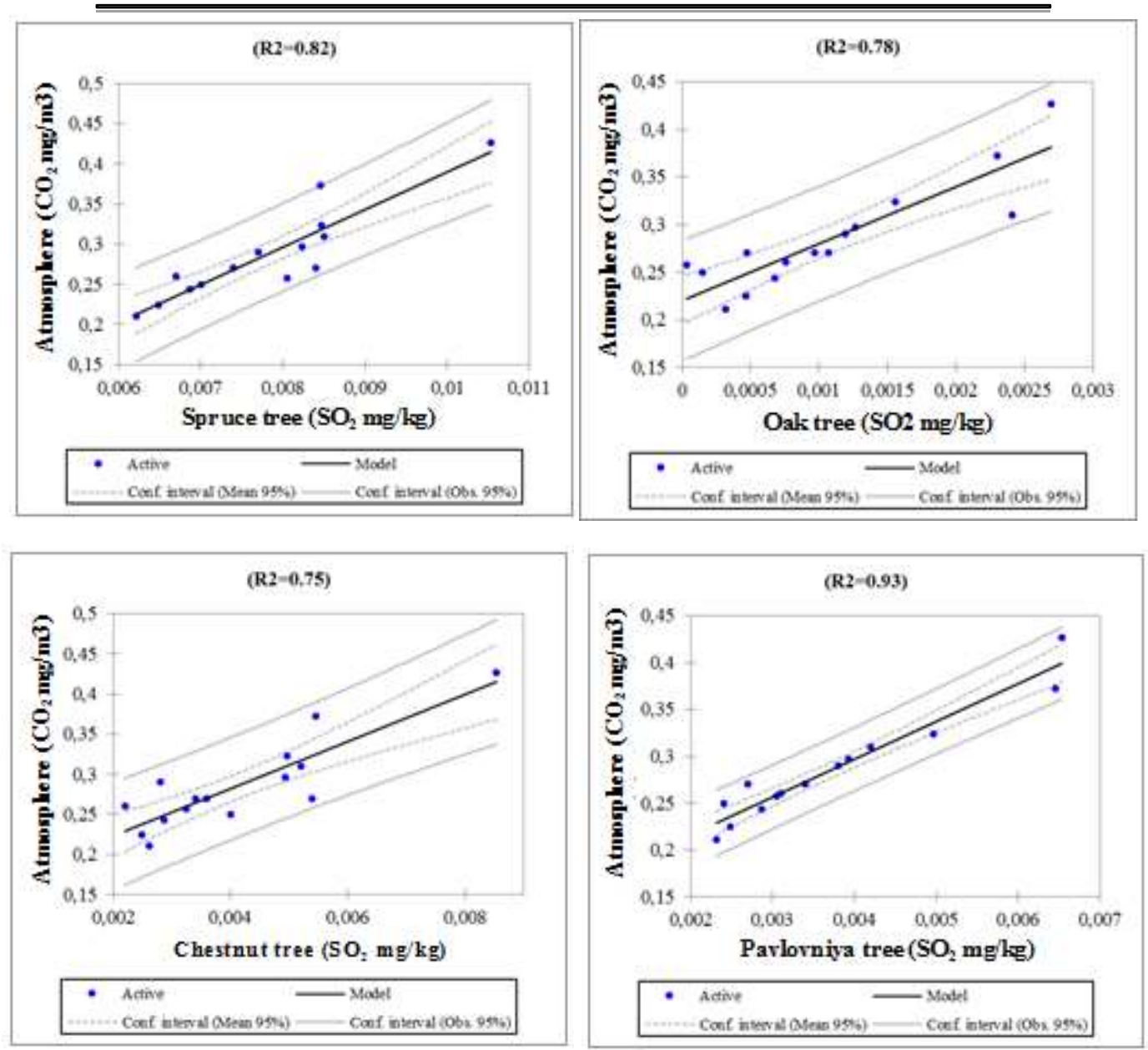

A) Sulfate is two oxides
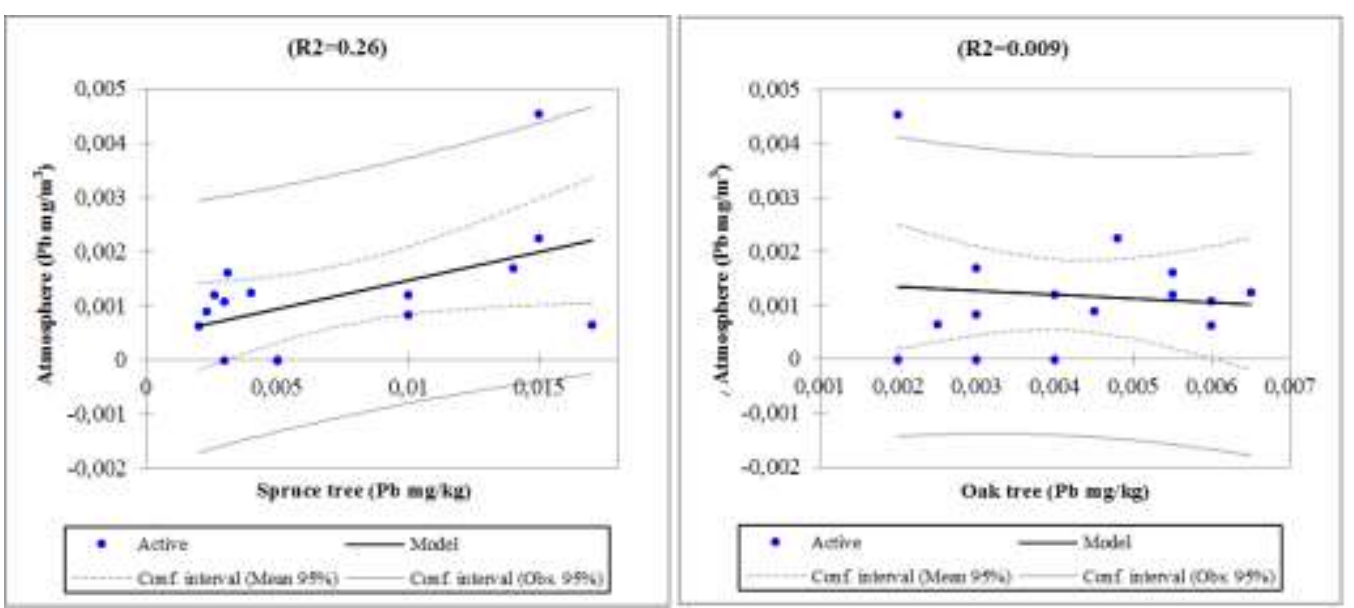

(C) 2021 EPRA IJRD | Journal DOI: https://doi.org/10.36713/epra2016 | www.eprajournals.com |234 | 


\section{EPRA International Journal of Research and Development (IJRD)}

Volume: 6 | Issue: 5 | May 2021 - Peer Reviewed Journal
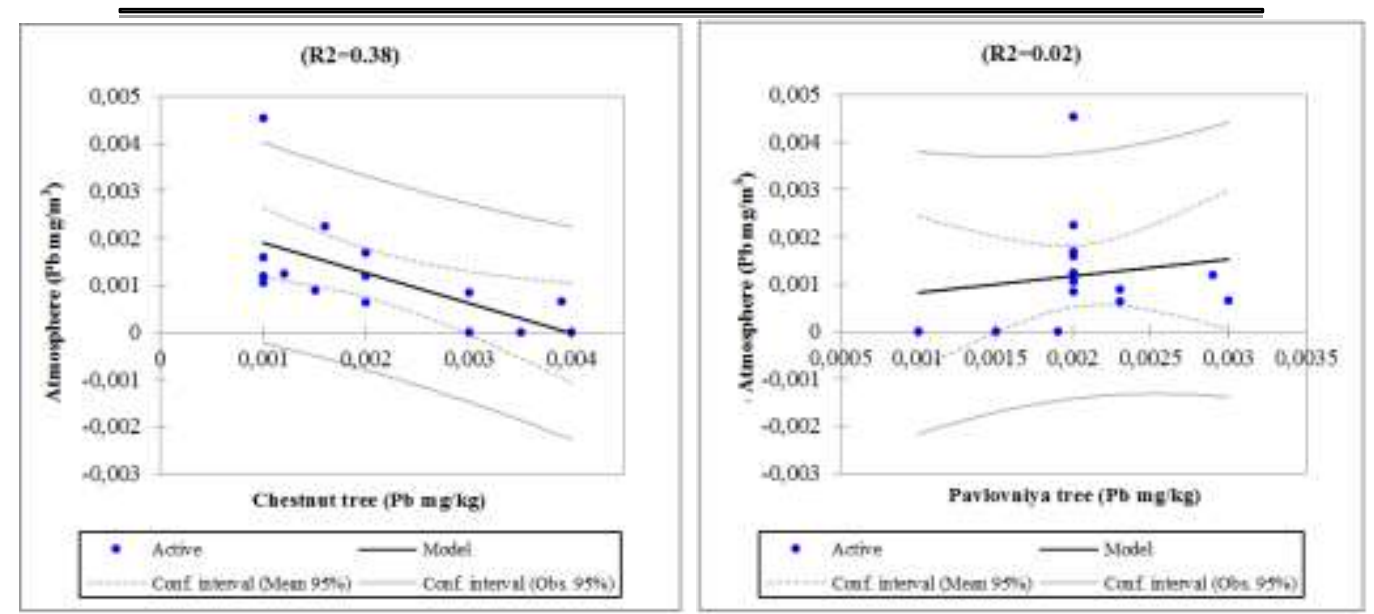

B) Lead substance

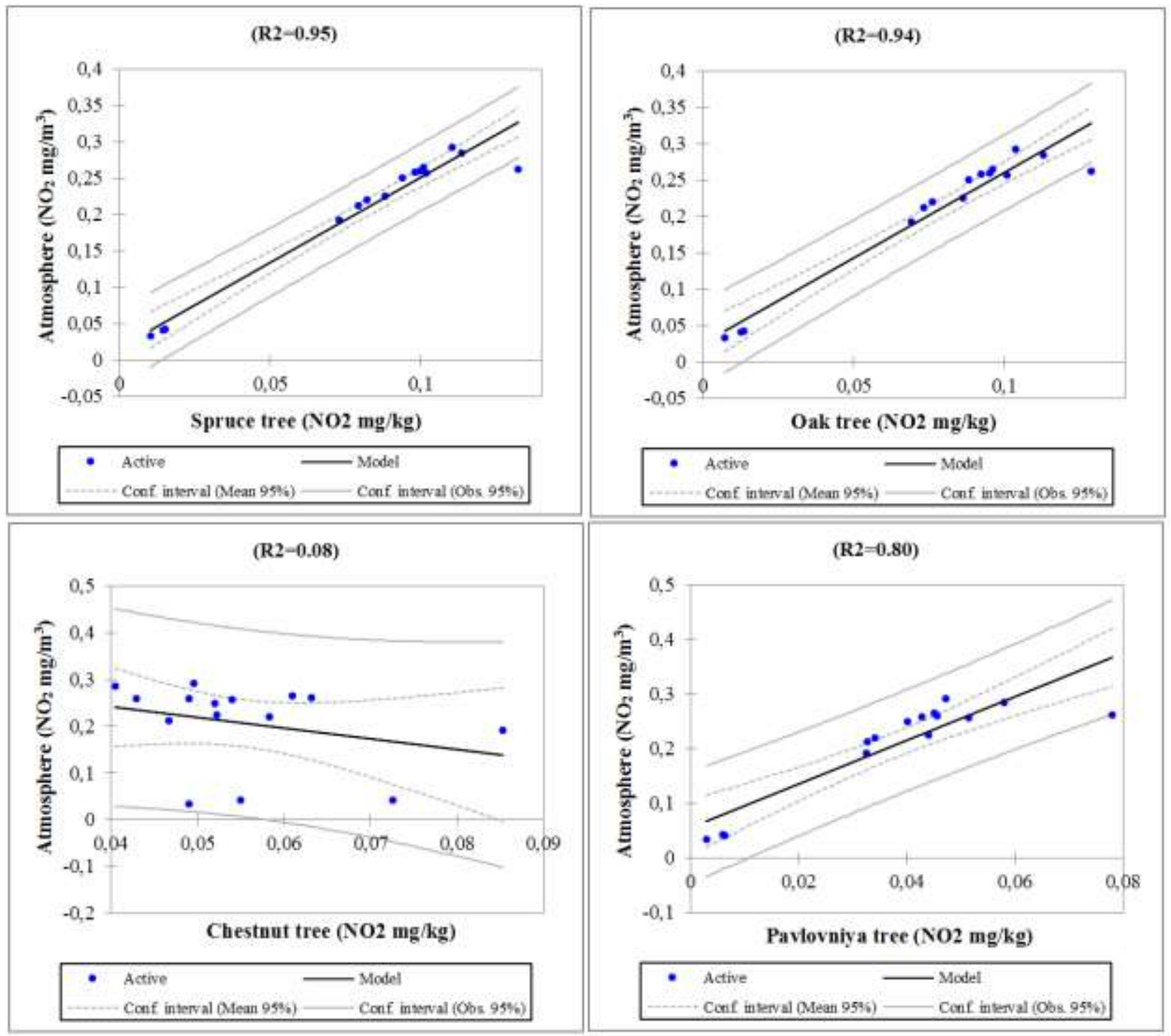

S) Nitric oxide

2021 EPRA IJRD | Journal DOI: https://doi.org/10.36713/epra2016 | www.eprajournals.com |235 | 


\section{EPRA International Journal of Research and Development (IJRD)}

Volume: 6 | Issue: 5 | May 2021

- Peer Reviewed Journal
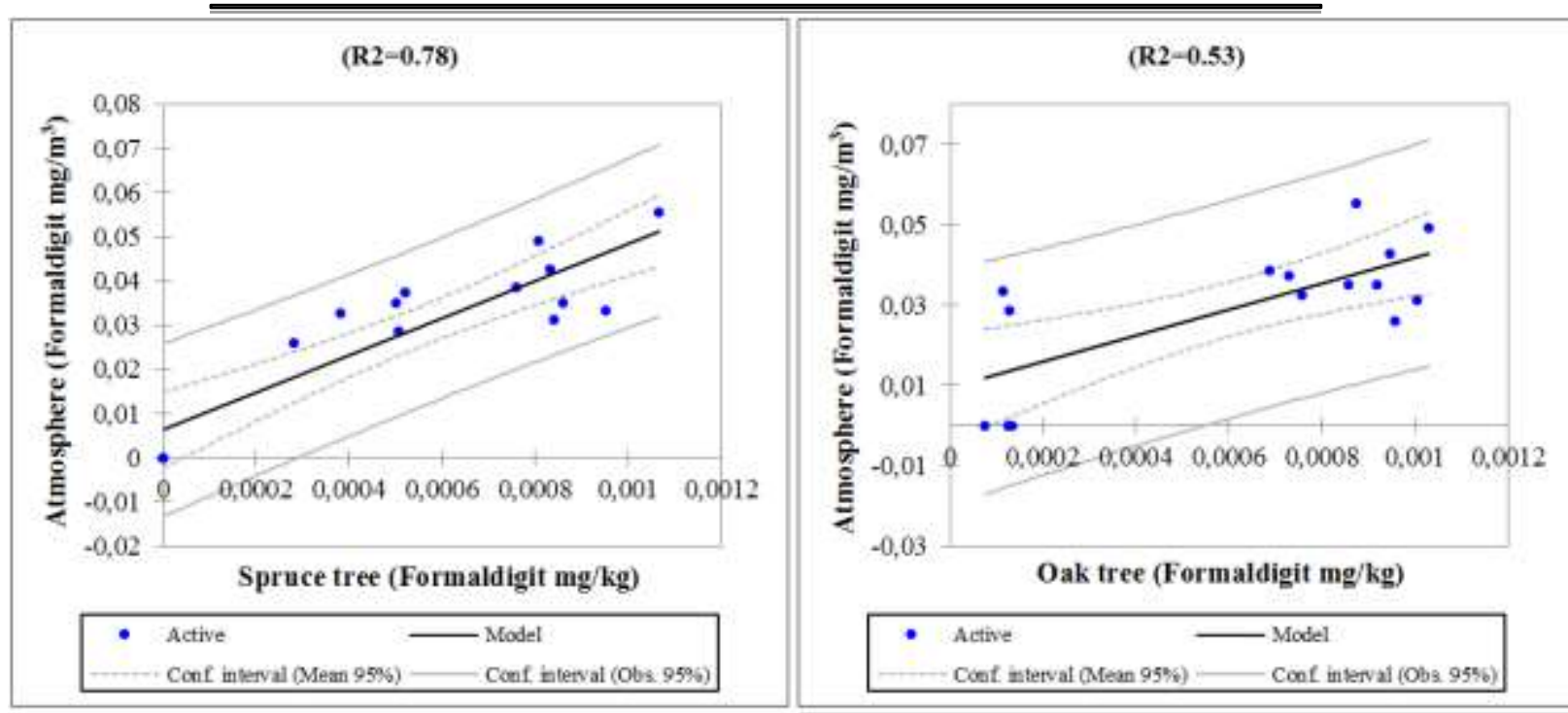

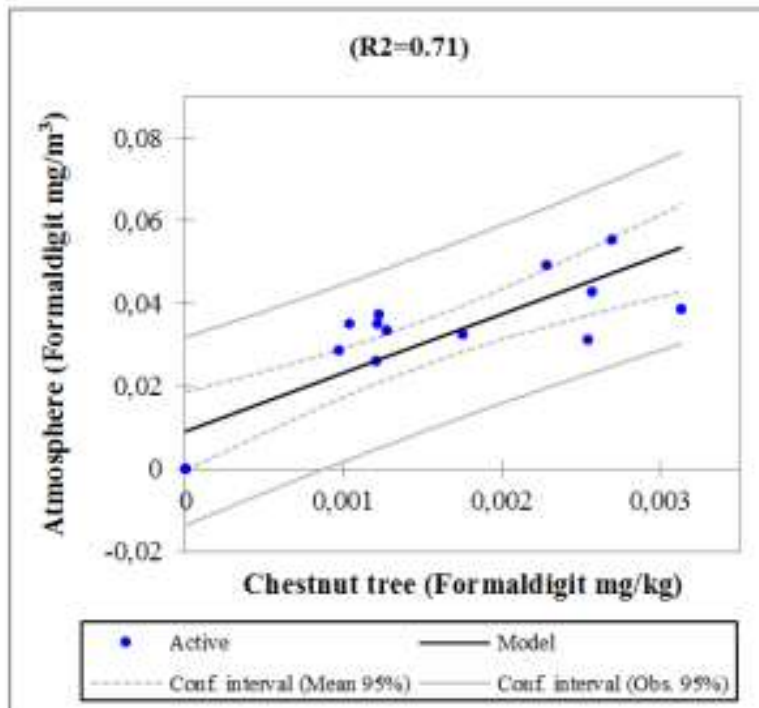

D) formaldehyde material

Figure 1. Results of a regression correlation model between atmospheric pollutants and their content in tree leaves (data formed as a result of three years of parallel field research)

The accumulation of lead material from heavy metals in a tree leaf leads to the development of two types of harmful processes. First, it has a harmful chemical effect, disrupts the chlorophyll process, and secondly, accumulates in the leaves and participates in the process of thermal burning. According to the modeling results, the bond strength between the concentration in the atmosphere and the cumulation in the tree leaf is weak. Even the accumulation in the leaves of the chestnut tree showed an inverse relationship (Table 2, Fig. 1, bband).

The link between atmospheric nitrogen oxides and cumulation in tree leaves is spruce, oak, and pavlo.showed that the vniya trees had a straight and strong connection, a weak connection with the
(R2 $=0.62)$

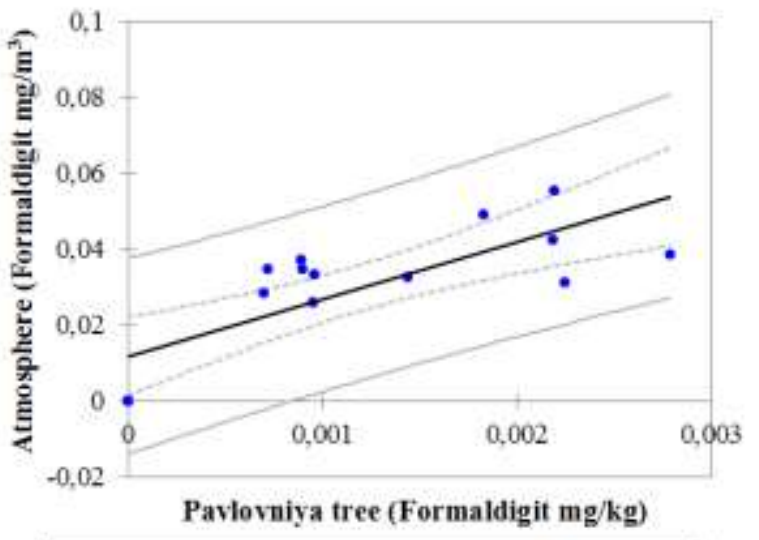

chestnut tree. Maximum concentrations of nitrogen dioxide in the atmosphere of up to $0.04 \mathrm{mg} / \mathrm{m} 3$ are important for nitrogen saturation of trees.

Formaldegid is one of the most harmful chemicals, its concentration above $0.02 \mathrm{mg} / \mathrm{m} 3$ causes cell death in tree leaves and spread of necrotic process. Concentrations in excess of this limit have been observed to develop even when the duration of exposure is 10 minutes [10]. It was found that there was a moderate correlation between the concentration of formaldehyde in the atmosphere and its amount in the leaves of the tree (Fig. 1, d-band).

\section{CONCLUSION}

In Andijan, it was found that there is a linear relationship between the accumulation of harmful substances in the atmosphere in the leaves of existing tree species isolated for research. The highest accumulation of harmful substances was observed in the leaves of the spruce tree, while the lowest rate was observed in the chestnut tree. Depending on the 


\section{SJIF Impact Factor 2021: 8.013| ISI I.F.Value:1.241| Journal DOI: 10.36713/epra2016 ISSN: 2455-7838(Online) \\ EPRA International Journal of Research and Development (IJRD) \\ Volume: 6 | Issue: 5 | May 2021 - Peer Reviewed Journal}

results of the analysis, the chestnut tree can be called the cleanest ecological tree.

The highest bond between the harmful substances was the nitrogen oxide contribution, while the lowest bond was the lead substance. The concentration of lead in the leaves of the chestnut tree is the concentration of this substance in the atmospherefound to be inversely related to age.

The study aimed to determine a linear relationship between the accumulation of harmful substances detected in the atmosphere in tree leaves, and this connection was proved.

\section{REFERENCES}

1. McLaughlin SB Effects of air pollution on forests // J. APCA (A ir Pollution Cont Association). 1985. Vol. 35. P. 512-534.

2. Alekseev V. A., Dochinjer L. S. Forest ecosystems and atmospheric pollution // Forestry. 1981. № 5. S. 64-71.

3. Vremennye normativy predelno dopustimyx kontsentratsiy zagryaznyayushchix veshchestv $v$ atmosfernom vozduxe, okazblvayushchix vrednoe vozdeystvie na lesnye nasajdeniya $v$ rayone muzea-usadby , Yasnaya Polyana”. M., 1984. 12 $p$.

4. Alekseev V. A. Diagnostics of life condition of trees and woods // Forestry. 1989. ^ 4. S. 51-57.

5. Eliseeva II, Yuzbashev MM. General theory of statistics. 5th ed. $M$.: Finance and Statistics, 2005.

6. Zaks L. Statisticheskoe otsenivanie M .: Statistika, 1976. - 598 p.

7. Zeldin M.A., Barinov N.P., Abbasov M.E. Doveritelnbly interval for srednego po vblborke iz konechnoy generalnoy sovokupnosti. PSMI Register otsenshchikov, №11, 2012, p.70-75

8. Mudd J. V. Biochemical effects of some air pollutants on plants // Air pollution damage to vegetation: Adv. Chem. 1973. Ser. 122. P. 3147.

9. Forest ecosystems and atmospheric pollution Under the editorship of $V$. A. Alekseeva - JL: Nauka, 1990. - 200 p.

10. Sovmestnbly promejutochnbly doklad o politicheski znachimyx nauchnyx vyvodax 2019 goda. Pyataya sovmestnaya session Geneva, 9-13 September 2019. ECE / EB.AIR / GE.1 / 2019/3

11. Pavlov I.N. Drevesnble rasteniya $v$ usloviyax technogennogo zagryazneniya - Ulan-Ude: BNTs SO RAN, 2005. - 370 p.

12. Grjibovskiy A.M., Unguryanu T.N. Analysis of biomedical data with the use of a package of statistical programs SPSS: uchebnoe posobie / A.M. Grjibovskiy, T.N. Unguryanu. Arkhangelsk: Izd-vo Severnogo gosudarstvennogo meditsinskogo universiteta, 2017. - 293 p. ISBN 978-5-91702-255-0 